\title{
NEW SOURCE MATERIAL FOR WINTER WHEAT BREEDING FOR RESISTANCE TO DISEASES
}

Luchna I. S.

Plant Production Institute nd. a V. Ya. Yuryev of NAAS

The results of immunological studies of winter wheat collection samples and hybrid families $\mathrm{F}_{6}-\mathrm{F}_{8}$ on infectious and provocative backgrounds of the most common diseases were analyzed.

\section{Winter wheat, source material, resistance, sources, samples, lines, hybridization}

Introduction. Currently, due to the intensification of agricultural production phytosanitary status of agrocenoses of all field crops is significantly complicated. Because of maximum saturation of crop rotations with common pathogens, the accumulation of them is observed in soil, seeds, stubble, wild cereals. This motivates the search for new ways to organize plant protection, development of revolutionary new approaches to solving this problem. One of the most efficient, but complex ways, is creation of resistant varieties, the most adapted to specific environmental conditions. Resistant varieties, due to their self-protection properties, solve economic, social and environmental challenges arising from the powerful pesticide pressure $[1,2]$. Breeding for resistance to diseaseis is is of immediate interest throughout the world because of economic and environmental factors. This is the most efficient and perfect, in terms of environmental protection, plant protection method. Recently, against the background of a rise in price of fungicides, on the one hand, and the ecological biosphere crisis, on the other hand, the search for new efficient sources of resistance to diseases and creation on this basis of new source material with group resistance to diseases [3, 4] take on enormous significance. Head smut, powdery mildew, leaf septoriosis, which under favorable conditions for their development can cause a significant loss in grain yield and quality deterioration of flour and bread remain the most harmful to winter wheat crops [5, 6]. In the Eastern Forest-Steppe of Ukraine, in particular the Kharkiv region, the greatest damage is caused by leaf spots (septoriosis, tan spot) and powdery mildew, appearing annually with varying degrees of disease development. For the last few years brown rust on winter wheat crops is not shown to a large extent.

Purpose. To realize successfully scientific breeding programs, source material is essential. Therefore, the search for new sources of resistance to diseases, determination of their donor properties and creation on their basis of new source material with a complex of valuable features are the mainstream directions of research.

Material and Methods. The study material was winter wheat collection samples and wheat lines $\mathrm{F}_{6}-\mathrm{F}_{7}$ derived from previously identified sources of resistance. The samples were immunologically characterized in the infectious provocative nursery of scientific crop rotation at the Plant Production Institute nd. a V. Ya. Yuryev of NAAS of Ukraine. Sowing was carried out in the optimal time frame for the culture (for leaf diseases) and later (to provoke head smut infection in plants) with hand drills, on 3-5 rows, each $1 \mathrm{~m}$ long, with the row spacing of $15-20 \mathrm{~cm}$ and bare fallow as a predecessor.

To create artificial infectious backgrounds of septoriosis (Septoria tritici Rob. et Desm, $S$. nodorum Berk.) and head smut (Tilletia caries Tul.) infective material gathered from soft winter wheat collection and breeding samples was used. Provocative backgrounds of brown leaf rust (Puccinia recondita f. sp., Tritici Rob. et Desm.) and powdery mildew (Blumeria graminis (DC) Speer.) were made by planting varieties-infection accumulators susceptible to diseases along

() I. S. Luchna. 2014.

ISSN 0582-5075. Selektsiia i nasinnytstvo. 2014. Vol 105. 
experimental plots and every 20 numbers. Counts of affected plants and determination of the resistance of samples under investigation were carried out according to the scales and procedures given in the methodological recommendations [7, 8]. The plant resistance to pathogens was assessed in dynamics; the assessment in the period of maximum development of diseases was considered the basic one.

Results. Phytosanitary status of all crops and winter wheat, in particular, is affected by all environmental factors and their fluctuations. Air and soil temperature and humidity, which influence spore germination, disease progression, changes in dominant hazardous species in pathogen populations, formation of new races, etc., are the most important for the development of fungal diseases in plants.

Recently sharp fluctuations of meteorological factors there have occurred: winters with subzero temperatures that are critical for wheat overwintering with almost frost-free ones alternate; years with dry conditions during the summer vegetation period prevail, and there are years with great amounts of precipitations, mainly shower rains. Almost every second year is characterized by moisture deficiency during the optimal planting terms, cases of late frosts are also noted, etc.

Weather conditions inhibit or provoke the development of various diseases, so a reliable estimation of collection and breeding material should be carried out on artificially formed infectious and provocative backgrounds. The study years (2011-2013) differed both in winter and in spring-summer weather conditions of winter wheat vegetation period.

The overwintering period during January - March in 2011 was rated as satisfactory, while the weather conditions in spring and summer months were favorable for the development of winter wheat leaf diseases and head smut. Deviations both in temperature and in the amount of precipitations upwards as compared with the long-term data were noted (Fig. 1, 2).

The amounts of precipitation in June and in July were remarkably different from the many year values $(63.3 \mathrm{~mm})-194.6 \mathrm{~mm}$ and $91 \mathrm{~mm}$, respectively, at a rather high temperature 20.8-23.0 ${ }^{\circ} \mathrm{C}$ on average per month, which was the impetus for the development of fungal diseases in plants.

The winter wheat overwintering in 2012 was complicated by the autumn drought, and then by the abnormally warm winter. Because of the sharp warming and drought in April and, as a consequence, a rapid recovery of winter crop vegetation, no snow mold on crops was observed.

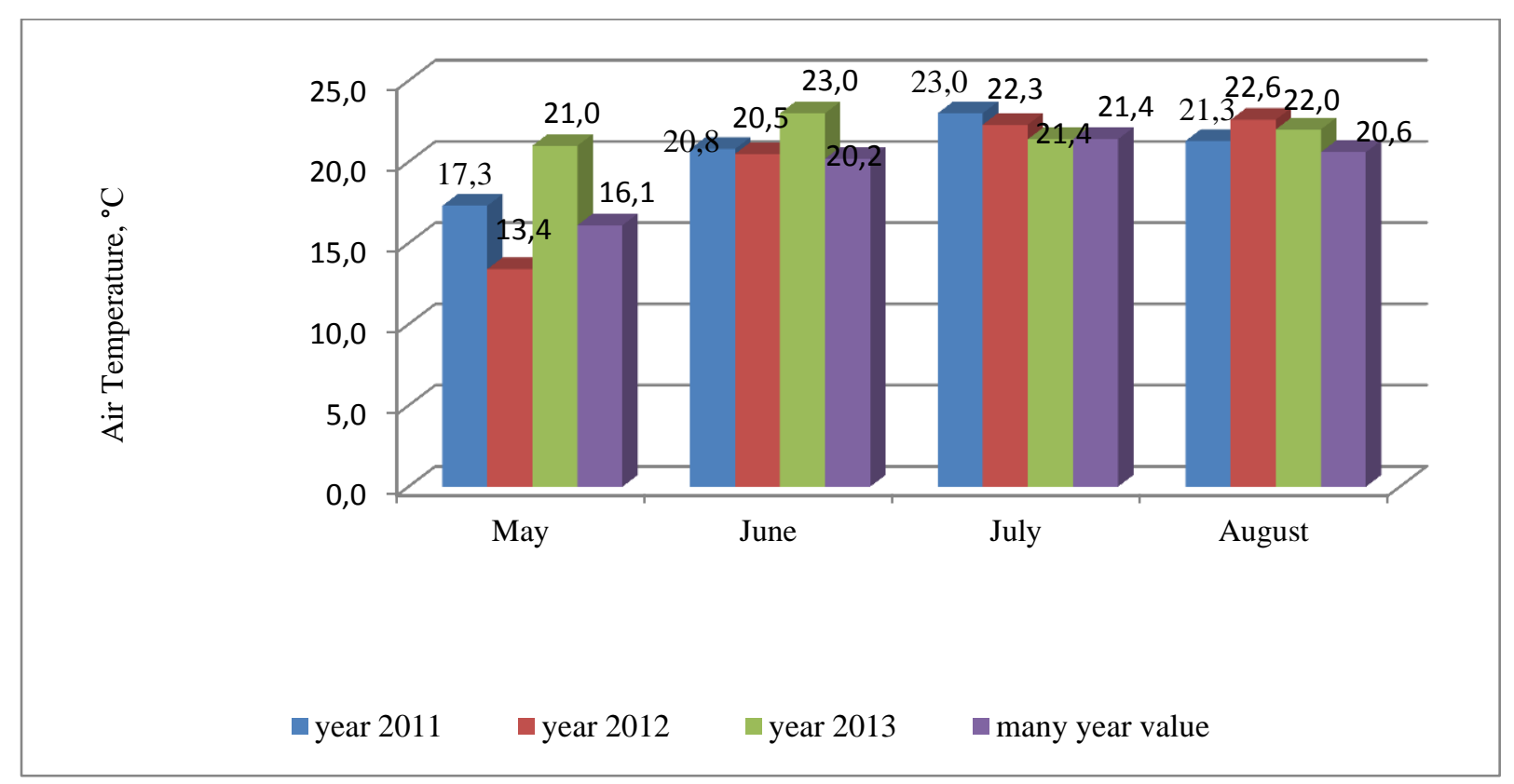

Fig. 1. The mean monthly air temperature in the spring and summer vegetation periods of winter crops 
The abundant May morning dew in 2012 contributed to infecting leaves by Septoria spot agents, but the pathological process was slowed down because of the subsequent drought in May, June and July (27.2, 48.3 and $20.3 \mathrm{~mm}$ of rainfall, respectively), high temperatures and low air humidity. The development of the powdery mildew pathogen, which is adapted to wider temperature and humidity ranges, continued in winter wheat plants.

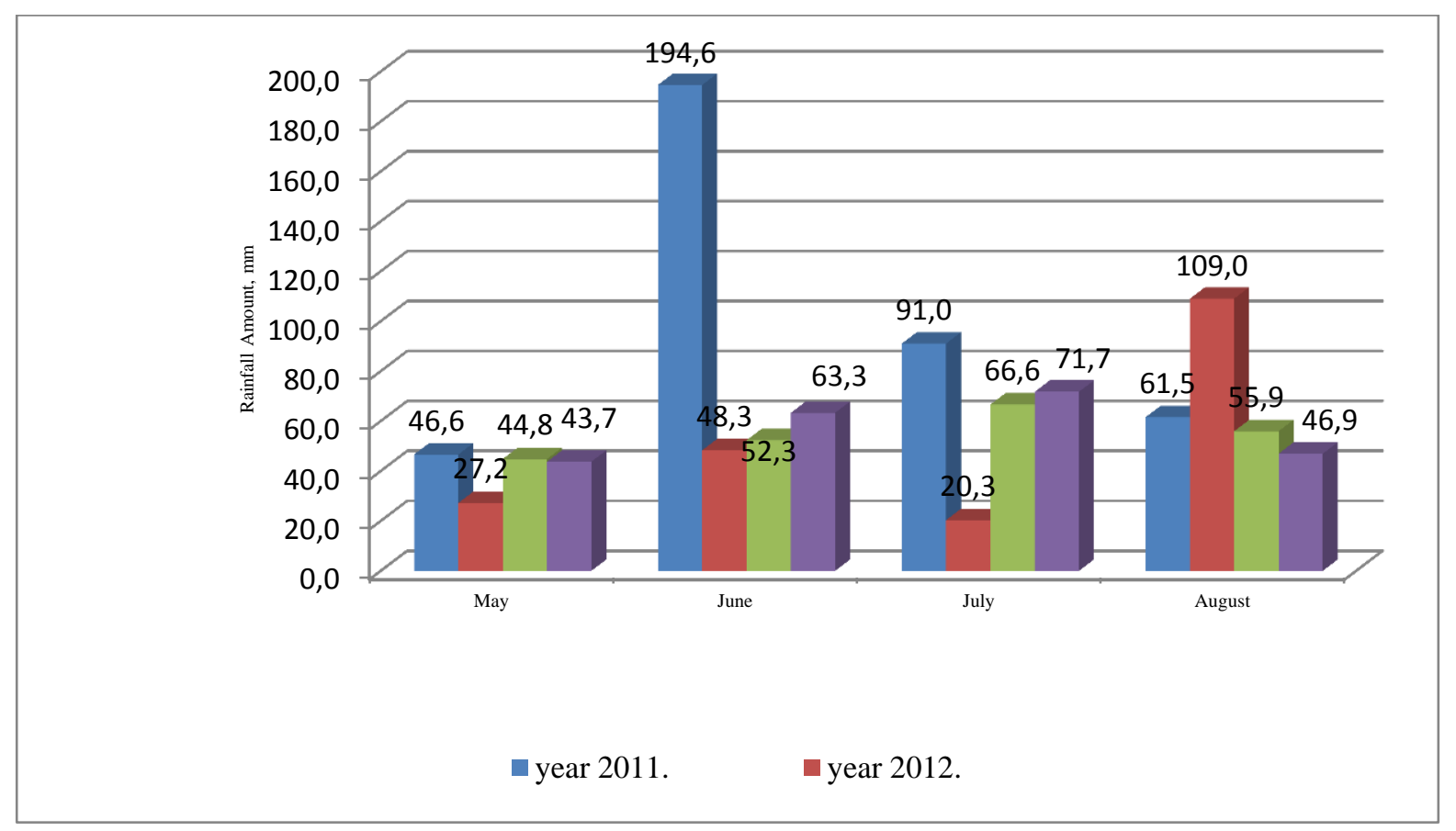

Fig. 2. The rainfall amounts in the spring and summer vegetation periods of winter crops

The winter in 2013 was rather mild; the minimum soil temperature at the depth of winter wheat tillering node did not drop below $-6{ }^{\circ} \mathrm{C}$. The overwintering of winter crops took place inder satisfactory conditions .

In the $1^{\text {st }}$ decade of April winter wheat vegetation resumed. Huge temperature swings, storms, frosts were observed. The first half of May was also very dry. On the last days of the $2^{\text {nd }}$ decade of May it rained, mainly shower rains were noted, on the whole $44.8 \mathrm{~mm}$ precipitated over this month. The improvement in soil moisturing and air humidity increasing contributed to the penetration and spore germination of fungal diseases - tan spot, leaf septoriosis, powdery mildew. In June the warm weather prevailed, the mean monthly temperature reached $22.9{ }^{\circ} \mathrm{C}$, the maximum temperature was $33.1^{\circ} \mathrm{C}$. The precipitations were irregular, mostly shower rains, (the precipitation amount per month was $52.3 \mathrm{~mm}$ ), the mean monthly relative humidity ranged from $40 \%$ to $88 \%$, while there were 11 days with the air humidity exceeding $60 \%$, the soil moisturing was satisfactory. In July the weather was unstable with heavy rains and temperature swings, especially at night and by day. The precipitation amount for July was $66.6 \mathrm{~mm}$; the air humidity ranged from $46 \%$ to $94 \%$, and in the $3^{\text {rd }}$ decade of July on all the days the humidity was above $60 \%$. No brown leaf rust was observed in plants, which is attributed to winter wheat ripening earlier than usual. Among the fungal diseases leaf ones prevailed - tan spot and septoriosis.

During the study years the levels of infectious and provocative backgrounds were sufficient to differentiate samples by resistance to the powdery mildew, septoriosis and head smut pathogens. The incidence in the susceptible varieties-standards over the study years ranged from 55 to $65 \%$ in the variety Borvyy (the reference variety of susceptibility to septoriosis), up to 40 $\%$ in the variety Agassis (the reference variety of susceptibility to powdery mildew), and from 70 to $90 \%$ in Donetskaya 48 (the reference variety of susceptibility ti head smut). The natural background of snow mold amounted to $90 \%$ in 2011 and 2013. During the study years rust diseases 
did not show a wide manifestation on winter wheat crops; the test material was not differentiated by resistance to them .

Since signs of diseases on winter wheat crops depend on meteorological factors, and disease intensity varies from year to year, a reliable estimate of collection and breeding material can be obtained only provided a minimum three-year study on infectious or provocative backgrounds of pathogens. After all, even if an infection is introduced and optimal conditions for its development are created, levels of infectious backgrounds vary from year to year. Every year the number of samples in nurseries of resistant forms reaches 100-150.

On the basis of the results of three-year studying sources of resistance were identified. Thus, over the period of 2011-2013 among the collection samples 6 sources of individual resistance were identified, of which 4 sources - to septoriosis (L- 25-OKH, Lutsina, Omskaya 6, Unikum), 2 sources - to head smut (Tarasovskaya/Belotserkovskaya, Polukarlik); 4 sources of group resistance to septoriosis and powdery mildew (KS 91112, IPM 296-06, Alana, Zarytsya); and 1 source of group resistance to powdery mildew and head smut (Ulya). The immunological parameters of the selected sources of resistance are summerized in Table 1.

Subsequently the sources selected will be crossed with susceptible varieties for hybridological analysis in $\mathrm{F}_{2}$ and estimation of their donor properties, ie their ability to propagate the resistance trait to offspring.

Another focus of work with the selected sources and donors of disease resistance is hybridizing them with highly productive and varieties adapted to the growing conditions with following selections from hybrid generations. For example, in 2013 seven constant lines, which were the best resistant to diseases according to the field counts, were selected from hybrid populations $\mathrm{F}_{6}-\mathrm{F}_{8}$, and the structural elements of their yield were analyzed (Table 2).

These lines are submitted for expert examination to the National Centre of Plant Genetic Resources of Ukraine (NCPGRU) with the following characteristics:

-LCH - 115-2012 - Podolyanka/AS-182 - resistance to powdery mildew of 6 points, resistance to septoriosis of 7 points, the capacity yield at the rate of the standard Podolyanka, 1000 -seed weight is higher than that of the standard.

Table 1

Sources of Resistance to Leaf Diseases and Head Smut, 2011-2013.

\begin{tabular}{|c|c|c|c|c|c|c|}
\hline \multirow{2}{*}{$\begin{array}{c}\text { No. in } \\
\text { sequence }\end{array}$} & \multirow{2}{*}{ No IR } & Sample & \multicolumn{4}{|c|}{ Resistance, score } \\
\cline { 4 - 7 } & & Septoriosis & $\begin{array}{c}\text { Powdery } \\
\text { mildew }\end{array}$ & Snow mold & Head smut \\
\hline 1 & 15180 & IPM 296-06 & 7 & 7 & 6 & - \\
\hline 2 & 13925 & Alana & 7 & 7 & 4 & - \\
\hline 3 & 13265 & KS 91112 & 7 & 7 & 4 & - \\
\hline 4 & 15110 & L-25-OKH & 7 & 5 & 5 & - \\
\hline 5 & - & Lutsina & 7 & 6 & 4 & - \\
\hline 6 & 14305 & Omskaya 6 & 7 & 6 & 6 & - \\
\hline 7 & 14787 & Unikum & 7 & 6 & 5 & - \\
\hline 8 & 15258 & Zarytsya & 7 & 7 & 6 & - \\
\hline 9 & 15268 & $\begin{array}{c}\text { Tarasovskaya / } \\
\text { Belotserkovskaya }\end{array}$ & 6 & 5 & 6 & 7 \\
\hline 10 & 15275 & Polukarlik & 5 & 6 & 6 & 7 \\
\hline 11 & 15265 & Yulya & 6 & 7 & 6 & 8 \\
\hline
\end{tabular}


Table 2

Characterization of Lines with Group Resistance to Powdery Mildew and Septoriosis, 2011-2013.

\begin{tabular}{|c|c|c|c|c|c|c|c|c|c|c|}
\hline \multirow[b]{2}{*}{ Line } & \multirow[b]{2}{*}{ 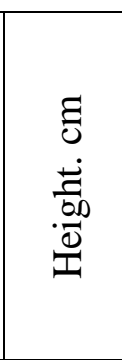 } & \multirow{2}{*}{ 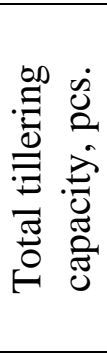 } & \multirow{2}{*}{ 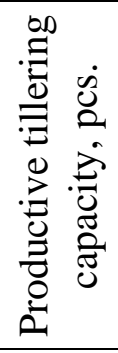 } & \multirow{2}{*}{ 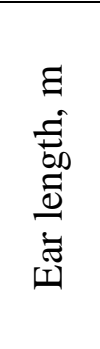 } & \multirow{2}{*}{ 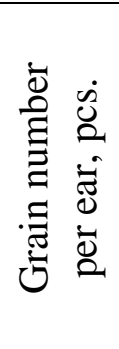 } & \multirow{2}{*}{ 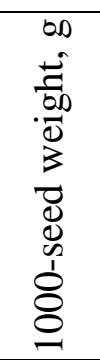 } & \multirow{2}{*}{ 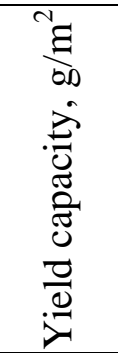 } & \multicolumn{3}{|c|}{$\begin{array}{l}\text { Resistance to } \\
\text { diseases, score }\end{array}$} \\
\hline & & & & & & & & 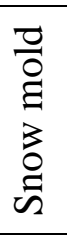 & 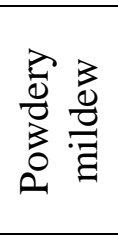 & 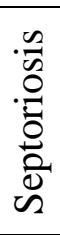 \\
\hline $\begin{array}{l}\text { The national standard } \\
\text { Podolyanka }\end{array}$ & 76.0 & 2.6 & 2.3 & 7.7 & 48.4 & 40.0 & 769.0 & - & 7 & 6 \\
\hline LCH 115-2012 & 90.2 & 3.1 & 2.9 & 7.4 & 44.7 & 43.0 & 786.6 & - & 6 & 7 \\
\hline LCH 117-2012 & 88.9 & 2.8 & 2.7 & 7.9 & 45.6 & 42.5 & 862.0 & - & 7 & 7 \\
\hline LCH 118-2012 & 90.1 & 2.8 & 2.6 & 8.0 & 43.4 & 38.5 & 630.3 & - & 7 & 7 \\
\hline LCH 821-2010* & 85.0 & 6.2 & 5.8 & 9.8 & 38.6 & 44.9 & 1013.3 & 7 & 5 & 7 \\
\hline LCH 853-2010* & 105.0 & 2.8 & 2.8 & 8.6 & 42.4 & 41.8 & 890.0 & 7 & 8 & 9 \\
\hline LCH 910-2010* & 90.0 & 2.0 & 1.6 & 10.3 & 53.0 & 45.6 & 1033.3 & 7 & 6 & 6 \\
\hline LCH 930-2010* & 95.0 & 1.6 & 1.2 & 11.5 & 65.0 & 44.5 & 638.3 & 7 & 7 & 7 \\
\hline $\begin{array}{l}\text { Borvyy (reference } \\
\text { variety of susceptibil- } \\
\text { ity to septoriosis) }\end{array}$ & 62.0 & 3.2 & 2.6 & 8.5 & 45.6 & 43.8 & 601.7 & 6 & 6 & 4 \\
\hline
\end{tabular}
2012.

* - According to the data of trials at the Ustimovskaya Experiment Station , 2011 and

- LCH - 117-2012 - Vasilisa/Olma - group resistance to diseases (powdery mildew and septoriosis), yield capacity and 1000-seed weight are higher than those of the standard;

LCH - 118-2012 - Vasilisa/Olma - group resistance to diseases (powdery mildew and septoriosis);

LCH - 821-2010 - Siouxland/AS-182 - resistance to septoriosis and snow mold, medium resistance to powdery mildew, high values of productive tillering capacity and yield capacity;

LCH 853-2010 - Kharus/NE93496 - group resistance to diseases (powdery mildew, septoriosis);

LCH 910-2010 - Vasilisa/Olma - resistance to powdery mildew of 6 points, resistance to septoriosis of 6 points;

LCH 930-2010 - Olma/Smuglyanka - resistance to powdery mildew of 7 points, resistance to septoriosis of 7 points.

In 2011 the last 4 lines were tested in the Kharkiv and Poltava regions (Ustimovskaya Experiment Station); the data of these tests are summerized in the characterization of the lines.

After undergoing expert review in the Laboratory of Genetic Resources of Cereals the line LCH 821/10 was registered in NCPGRU and itemized under No. UA0108203 in the National Catalog and under Rregistration Certificate No. 1176; the line LCH 117/12 - UA0108195 and No 1175, respectively, d/d 25 February 2014. The lines registered are new valuable source material for breeding, since they combine group resistance to leaf diseases (7 points ), resistance to biotic factors (frost resistance of 6.5-7 points) and high yield capacity $\left(790-800 \mathrm{~g} / \mathrm{m}^{2}\right.$ ).

Conclusions. Thus, as a result of immunological assay conducted on artificial infectious and provocative backgrounds for the last three study years (2011-2013) sources of individual (6 samples) and group (5 samples) resistance to leaf diseases and head smut were identified. By hybridization and multiple selections on infectious and provocative backgrounds seven new lines with a complex of valuable economic characteristic, which can be used as improved donors in breeding programs, were created. The two best lines are registered in NCPGRU (Certificate Nos. $1175,1176 \mathrm{~d} / \mathrm{d} 25.02 .2014)$. 


\section{References}

1. Yevtushenko MD, Lisovii MP, Panteleiev VK, Slisarenko OM. 2004. Plant immunity. Kyiv: Kolobig. 303 p.

2. Petrenkova VP, Chernobay LM, Cherniaieva IM, Markova TYu, Krivosheieva OV. 2007. Immunological principles of breeding agricultural plants. In: Theoretical principles of breeding field crops: collection of scientific papers. Kharkiv. p. 260-278.

3. Motsnii II, Blagodarova OM. 2004. Inheritance of disease resistance and morphological traits in soft wheat hybrids with introgressive lines. Collection of scientific papers of Institute of Plant Breeding and Genetics. 6(46):179-193.

4. Kovalishina GM. 2003. Study results of winter wheat breeding for immunity to diseases. Collection of scientific papers of Institute of Plant Breeding and Genetics. 4 (44):68-76.

5. Kovalishina GM. 2006. Influence of meteorological factors on the degree of damage in Myroniv winter wheat varieites by brown rust. Zakhist I karantine roslin. 52:101-109.

6. Melnikova MP. 2006. Powdery mildew and creation of winter wheat breeding material resistant to it in the Forest-Steppe of Ukraine. Scientific and Technical Bulletin of Myroniv Institute of Wheat. 5:60-72.

7. Babaiants LT et al. 1988. Methods for breeding and evaluation of wheat and barley resistance in the CMEA countries. Praga. p.193-208.

8. Pizhikova GV, Sanina AA, Suprun LM et al. editors. 1989. Methods for assessment of wheat breeding material and variety resistance to septoriosis [Guidelines]. Moskva. 43 p. 


\title{
НОВЫЙ ИСХОДНЫЙ МАТЕРИАЛ ДЛЯ СЕЛЕКЦИИ ПШЕНИЦЫ ОЗИМОЙ НА УСТОЙЧИВОСТЬ К БОЛЕЗНЯМ
}

\author{
Лучная И. С.
}

Институт растениеводства им. В. Я. Юрьева НААН

Проанализированы результаты иммунологических исследований коллекционных образцов и гибридных семей пшеницы озимой $\mathrm{F}_{6}-\mathrm{F}_{8}$ на инфекционных и провокационных фонах наиболее распространенных болезней.

Вступление. В настоящее время из-за интенсификации сельскохозяйственного производства фитосанитарное состояние агроценозов всех полевых культур значительно усложнилось. Это побуждает к поиску новых путей организации защиты растений, разработки принципиально новых подходов к решению этой проблемы. Одним из самых эффективных, но сложных путей является создание устойчивых сортов, максимально адаптированных к конкретным условиям окружающей среды.

Цель. Для успешного выполнения научных селекционных программ исходный материал имеет важное значение. Поэтому поиск новых источников устойчивости к болезням, определение их донорских свойств и создания на их основе нового исходного материала с комплексом ценных признаков является актуальным направлением исследований.

Материал и методика. Материалом для исследований были коллекционные образцы озимой пшеницы и полученные на основе выделенных ранее источников устойчивости линии пшеницы $\mathrm{F}_{6}-\mathrm{F}_{7}$. Иммунологическую характеристику образцов определяли в инфекционно-провокационном питомнике научного севооборота Института растениеводства им. В. Я. НААН Украины. Посев проводили в оптимальные для культуры сроки (для листовых болезней) и в более поздние (для провокации заражения растений твердой головней) ручными сеялками, на 3-5 рядах длиной 1 м, с шириной междурядий 15$20 \mathrm{~cm}$, по предшественнику черный пар. Учеты пораженности растений и определение устойчивости исследуемых образцов проводили по приведенным в методических рекомендациях шкалам и методикам.

Результаты исследований. По результатам трехлетнего изучения определяли источники устойчивости. Так, за 2011-2013 годы среди коллекционных образцов выделено шесть источников индивидуальной устойчивости, из которых четыре источника - к септориозу (L-25-OKH, Люцина, Омская 6, Уникум), два источника - к твердой головне (Тарасовская/Белоцерковская, Полукарлик), четыре источника групповой устойчивости к септориозу и мучнистой росе (KS 91112, IPM 296-06, Alana, Зариця ) и один источник групповой устойчивости к мучнистой росе и твердой головне (Уля). Из гибридных популяций $\mathrm{F}_{6}-\mathrm{F}_{8}$, созданных с участием ранее выделенных источников устойчивости, по данным полевых учетов отобрано семь лучших по устойчивости к болезням константных линий и проведен анализ элементов структуры их урожая. Это линии ЛЧ 115-2012, ЛЧ 117-2012, ЛЧ 118-2012, ЛЧ 821-2010, ЛЧ 853-2010, ЛЧ 910-2010, ЛЧ 930-2010.

Выводы. В результате проведенной на искусственных инфекционных и провокационных фонах иммунологической работы за последние три года исследований (2011-2013 гг.) выделены источники индивидуальной (шесть образцов) и групповой (пять образцов) устойчивости к листовым болезням и твердой головне. Путем гибридизации и многократных отборов на инфекционных и провокационных фонах создано семь новых линий с комплексом ценных хозяйственных признаков, которые могут быть использованы как улучшенные доноры в селекционных программах. Две лучшие линии зарегистрированы в НЦГРРУ (№ свидетельств 1175, 1176 от 25.02.2014 г.).

Пшеница озимая, исходньй материал, устойчивость, источники, образцы, линии, гибридизаџия 


\section{НОВИЙ ВИХІДНИЙ МАТЕРІАЛ ДЛЯ СЕЛЕКЦЇ̈ ПШЕНИЦІ ОЗИМОЇ НА СТІЙКІСТЬ ДО ХВОРОБ}

Лучна I. C.

Інститут рослинництва ім. В.Я. Юр'єва НААН

Наведено результати вивчення колекційних зразків пшениці озимої та гібридних сімей $\mathrm{F}_{6}$ $\mathrm{F}_{8}$ на інфекційних та провокаційних фонах найбільш розповсюджених та шкідливих у регіоні хвороб.

Вступ. На теперішній час через інтенсифікацію сільськогосподарського виробництва фітосанітарний стан агроценозів усіх польових культур значно ускладнився. За максимального насичення сівозмін культурами зі спільними збудниками хвороб спостерігається накопичення їх у грунті, насінні, на пожнивних залишках, дикорослих злаках. Одним із самих ефективних, але не легких шляхів є створення стійких сортів.

Мета. Пошук нових джерел стійкості до хвороб, визначення їх донорських властивостей і створення на їх основі нового вихідного матеріалу з комплексом цінних ознак $є$ актуальним напрямом досліджень.

Матеріал і методика. Матеріалом для дослідів були колекційні зразки пшениці озимої та отримані на основі визначених раніше джерел стійкості лінії пшениці $\mathrm{F}_{6}-\mathrm{F}_{7}$. Обліки ураженості рослин та визначення стійкості досліджуваних зразків проводили за наведеними в методичних рекомендаціях шкалами і методиками.

Результати досліджень. Серед колекційних зразків виділено шість джерел індивідуальної стійкості, з яких чотири джерела - до септоріозу, два джерела - до твердої сажки, чотири джерела групової стійкості до септоріозу та борошнистої роси та одне джерело групової стійкості до борошнистої роси та твердої сажки. 3 гібридних популяцій $\mathrm{F}_{6}-\mathrm{F}_{8}$ за даними польових обліків відібрано сім кращих за стійкістю до хвороб константних лінії та проведено аналіз елементів структури їх урожаю.

Висновки. В результаті проведеної на штучних інфекційних та провокаційних фонах імунологічної роботи за останні три роки досліджень (2011-2013 рр.) визначено джерела індивідуальної (шість) та групової (п'ять) стійкості до листкових хвороб та твердої сажки. Шляхом гібридизації та багаторазових доборів на інфекційних та провокаційних фонах створено сім нових ліній з комплексом цінних господарських ознак, які можуть бути використані як покращені донори в селекційних програмах. Дві кращі лінії зареєстровано в НЦГРРУ (№ свідоцтв 1175, 1176 від 25.02.2014р.).

Пшениия озима, вихідний матеріал, джерела, зразки, лінії, гібридизація

\section{NEW SOURCE MATERIAL FOR WINTER WHEAT BREEDING FOR RESISTANCE TO DISEASES}

Luchna I. S.

Plant Production Institute nd. a V. Ya. Yuryev of NAAS

Introduction. Currently, due to the intensification of agricultural production phytosanitary status of agrocenoses of all field crops is significantly complicated. This motivates the search for new ways to organize plant protection, development of revolutionary new approaches to solving this problem. One of the most efficient, but complex ways, is creation of resistant varieties, the most adapted to specific environmental conditions.

Purpose. To realize successfully scientific breeding programs, source material is essential. Therefore, the search for new sources of resistance to diseases, determination of their donor properties and creation on their basis of new source material with a complex of valuable features are the mainstream directions of research. 
Material and Methods. The study material was winter wheat collection samples and wheat lines $\mathrm{F}_{6}-\mathrm{F}_{7}$ derived from previously identified sources of resistance. The samples were immunologically characterized in the infectious provocative nursery of scientific crop rotation at the Plant Production Institute nd. a V.Ya. Yuryev of NAAS of Ukraine. Sowing was carried out in the optimal time frame for the culture (for leaf diseases) and later (to provoke head smut infection in plants) with hand drills, on 3-5 rows, each $1 \mathrm{~m}$ long, with the row spacing of 15-20 $\mathrm{cm}$ and bare fallow as a predecessor. Counts of affected plants and determination of the resistance of samples under investigation were carried out according to the scales and procedures given in the methodological recommendations.

Results. On the basis of the results of three-year studying sources of resistance were identified. Thus, over the period of 2011-2013 among the collection samples 6 sources of individual resistance were identified, of which 4 sources - to septoriosis (L-25-OKH, Lutsina, Omskaya 6, Unikum), 2 sources - to head smut (Tarasovskaya/Belotserkovskaya, Polukarlik); 4 sources of group resistance to septoriosis and powdery mildew (KS 91112, IPM 296-06, Alana, Zarytsya); and 1 source of group resistance to powdery mildew and head smut (Ulya). Seven constant lines, which were the best resistant to diseases according to the field counts, were selected from hybrid populations $\mathrm{F}_{6}-\mathrm{F}_{8}$, and the structural elements of their yield were analyzed. These are lines LCH 115-2012, LCH 117-2012, LCH 118-2012, LCH 821-2010, LCH 8532010, LCH 910-2010, and LCH 930-2010.

Conclusions. As a result of immunological assay conducted on artificial infectious and provocative backgrounds for the last three study years (2011-2013) sources of individual (6 samples) and group (5 samples) resistance to leaf diseases and head smut were identified. By hybridization and multiple selections on infectious and provocative backgrounds seven new lines with a complex of valuable economic characteristic, which can be used as improved donors in breeding programs, were created. The two best lines are registered in NCPGRU (Certificate Nos. 1175, $1176 \mathrm{~d} / \mathrm{d}$ 25.02.2014).

Winter wheat, source material, resistance, sources, samples, lines, hybridization 